\title{
二次元フォーストプルームの連行係数に関する理論的研究
}

\section{THEORETICAL ANALYSIS OF TURBULENT ENTRAINMENT IN PLANE FORCED PLUME}

\author{
室田 明*.中辻啓二**.中井正則*** \\ By Akira MUROTA, Keiji NAKATSUJI and Masanori NAKAI
}

\begin{abstract}
The behavior throughout all over a plane forced plume is predicted by a differential and integral hybrid model. The differential boundary layer equations are used to develop an integral formulation which can describe the streamwise variations of mass, momentum and buoyancy fluxes. The eddy viscosity coefficient connects with the entrainment coefficient in this theoretical derivation. It enables to derive a relationship between the entrainment velocity and the Richardson number theoretically. It shows that the entrainment coefficient increases from 0.065 for a jet to 0.156 for a plume with an increase of the Richardson number. It is found that this model reasonably predicts the distributions of mean velocity, mean buoyancy and Reynolds stress and their streamwise variations.
\end{abstract}

\section{1. 緒言}

フォーストプルームは周囲流体と密度の異なる噴流の 流動を示す.その流動形態は, 初期には運動量流束の卓 越した噴流的挙動（jet-like flow）を呈する. 放流口か らの距離が大きくなるにつれて浮力流束がしだいに優勢 となり，それはプルーム的挙動 (plume-like flow) に 移行する. 均質噴流あるいはプルームの解析理論は枚挙 にいとまがないほど数多く提案されている．しかし，噴 流からプルームに至るフォーストプルームの全流程にわ たる水理特性を明確にするような理論はない.

Phillips ${ }^{1)}$ は任意点での水理諸量を断面積分量と無次 元の分布関数との積で表現することにより, 従来の微分 モデルと積分モデルの利点をうまく活用した理論展開 （以下では混成モデルと称する）を提案している.それ は, 流速や温度の分布関数形を特定することなく, 連行 係数とリチャードソン数との関数関係を理論的に誘導で きるという特色を有する.

しかしながら, Phillips 自身が指摘するように，その

* 正会員 工博 大阪大学教授 工学部土木工学科 (テ565 吹田市山田丘 2-1)

** 正会員 工博 大阪大学助教授 工学部土木工学科(同上)

*** 学生会員 大阪大学大学院工学研究科前期課程学生(同上)
関数関係は $\mathrm{Fox}^{2)}$ の提案式と少し異なっている. また, 著者らの検討 ${ }^{3)}$ によっても, その混成モデルは連行係数 を少し過小評価する傾向にある.フォーストプルームの 全流程にわたる流動特性を予測するためには, 物理的に 容認しがたい, 極端に小さな乱流プラントル数を導入し なければならないという欠陥がある，その原因として， 乱流せん断応力の表現のまずさが考えられる. 最近の精 度よい測定結果 ${ }^{4}$ によれば，軸上の流速および浮力で基 準化した乱流せん断応力や乱流熱流束を比較した場合, プルームの值は均質噴流の值より $1.4 \sim 1.6$ 倍大きいこ とがわかってきた。この差異が連行現象にもたらす影響 は非常に大きい.

そこで, 本研究では乱流せん断応力の流下方向変化を 理論的に評価することにより混成モデルの改善を図り, フォーストプルームの全流程の特性を一貫して記述する 理論展開を試みる.つまり, 乱流境界層の微分方程式を 基礎に, 運動量流束, 浮力流束および流量の流下方向保 存則との結合から, 連行係数を理論的に求める. さらに 実験結果との比較から, 提案モデルの適合性を検証する.

\section{2. 基礎方程式}

鉛直上向きに放出された二次元フォーストプルームに 境界層近似とブーシネスク近似が適用できるものと仮定 
する. 連続方程式, プルームの軸方向運動方程式ならび に浮力の拡散方程式は次のようになる.

$$
\begin{aligned}
& \frac{\partial U}{\partial x}+\frac{\partial V}{\partial y}=0 \\
& U \frac{\partial U}{\partial x}+V \frac{\partial U}{\partial y}=B+\varepsilon_{M} \frac{\partial^{2} U}{\partial y^{2}} \\
& U \frac{\partial B}{\partial x}+V \frac{\partial B}{\partial y}=\frac{\varepsilon_{M}}{P_{r}} \frac{\partial^{2} B}{\partial y^{2}}
\end{aligned}
$$

また，境界条件は，

$$
\begin{aligned}
& V(x, 0)=0, \frac{\partial U}{\partial y}(x, 0)=0, \quad U(x, \infty)=0 \\
& \frac{\partial B}{\partial y}(x, 0)=0, \quad B(x, \infty)=0
\end{aligned}
$$

である.ここに， $x$ : プルーム軸 (鈶直) 方向座標, $y$ : プルーム軸直角 (横) 方向座標, $U(x, y): x$ 方向平 均流速, $V(x, y): y$ 方向平均流速, $B(x, y)=$ $\left(\rho_{a}-\rho\right) g / \rho_{a}$ : 浮力, $\rho$ : 密度, $\rho_{a}$ : 周囲環境水密度, $g$ : 重力加速度, $\varepsilon_{M}(x)$ : 渦動粘性係数, $\varepsilon_{K}(x)$ : 渦動拡 散係数, $P_{r}=\varepsilon_{M} / \varepsilon_{K}$ : 乱流プラントル数である.

\section{Phillips の混成モデルの概要}

\section{（1）変数 分 離}

Phillips が提案したモデルの特徴の 1 つは, 微分モデ ルと積分モデルの利点をうまく活用するために, 任意点 での水理量を断面積分した水理量と無次元の横方向分布 関数形との積で表現する変数分離を採用したことであ る.

古典的微分モデルにおいては流速あるいは温度は軸上 代表值と相似分布関数との積で $x^{n} \cdot f\left(y / x^{m}\right)$ で表示さ れ, 支配方程式を直接解くことによって解が得られる. したがって, 微分モデルでは, 浮力流束が 0 の均質噴流 か，あるいは運動量流束と浮力流束とが均衡して分布形 状が流下方向に変化しないプルームに対してのみ, 解が 存在することになる.つまり，両流束が同時に影響を及 ぼすようなフォーストプルームに対して微分モデルは適 用できない。

一方, 積分モデルは流速・温度の相似分布形（たとえ ば, $U_{\varepsilon}(x) \cdot f\left(y / W_{U}\right)$, ここに, $U_{\mathfrak{q}}(x)$ : 軸上流速, $W_{U}$ : 流速の半値半幅を示す）をプルーム軸に直交する断面で 積分した流束の流下方向保存則を基礎に展開される. 運 動量流束と浮力流束が流下方向に変化するフォーストプ ルームに対しても, 積分モデルは適用可能である. その 反面, 方程式の数の不足加周囲流体の連行量を付加的 条件として実験的に定めざるを得ないという欠点があ る.このように, フォーストプルームの全流程の流動を 記述できる理論はない.

そこで, Phillips は両モデルを融合する目的で, 流れ
関数 $\phi(\partial \psi / \partial y=U, \partial \psi / \partial x=-V)$, 浮力 $B$ および $y$ 方向距離 $\zeta$ に対して次式のような変数分離を採用した。

$$
\begin{aligned}
& \left.\begin{array}{l}
\psi(x, y)=Q(x) \cdot f(\zeta) \\
B(x, y)=D(x) \cdot \theta(\zeta) \\
\zeta(x, y)=y / W(x)
\end{array}\right\} \ldots \ldots \ldots . . \\
& \text { ここに, } \\
& Q(x)=2 \int_{0}^{\infty} U(x, y) d y \\
& D(x)=\frac{2}{W(x)} \int_{0}^{\infty} B(x, y) d y \\
& W(x)=Q^{2}(x) / 2 \int_{0}^{\infty} U^{2}(x, y) d y
\end{aligned}
$$

すなわち, 微分方程式系における未知分布関数形 $f(\zeta)$, $\theta(\zeta)$ と積分方程式系における断面積分量 $Q(x), D(x)$ お よびプルーム幅 $W(x)$ との積で任意点での流速 $U(x$, $y), V(x, y)$ および浮力 $B(x, y)$ を表現した.

流れ関数は式(1)の関係を満たしているので,式( 5 ), （6）を式（2）（4）に代入すると, 微分方程式系の 基礎式として次式が得られる.

$$
f^{\prime \prime \prime}+\frac{W}{\varepsilon_{M}} \frac{d Q}{d x}\left(f f^{\prime \prime}-f^{\prime 2}\right)+\frac{Q}{\varepsilon_{M}} \frac{d W}{d x} f^{\prime 2}+\frac{D W^{3}}{\varepsilon_{M} Q} \theta=0
$$

$$
\begin{aligned}
& \theta^{\prime \prime}-\frac{P_{r}}{\varepsilon_{M}} \frac{W Q}{D} \frac{d D}{d x} f^{\prime} \theta+\frac{P_{r} W}{\varepsilon_{M}} \frac{d Q}{d x} f \theta^{\prime}=0 \\
& f(0)=0, f^{\prime \prime}(0)=0, \quad f^{\prime}(\infty)=0 \\
& \theta^{\prime}(0)=0, \quad \theta(\infty)=0
\end{aligned}
$$

また, 式（5）を代入した，運動方程式（2）と浮力 拡散方程式（3）をとに関して 0 から 0 まで積分する ことによって, 運動量流束ならびに浮力流束の流下方向 保存方程式が誘導される. その過程で分布関数形 $f(\zeta)$, $\theta(\zeta)$ が消去されて, 断面積分量 $Q(x), D(x), W(x)$ のみ で表現される積分方程式系の基礎式が得られる.

$$
\begin{aligned}
& \frac{d}{d x}\left(\frac{Q^{2}}{W}\right)=D W \\
& \frac{d}{d x}(Q D)=0 \cdots
\end{aligned}
$$

\section{（2）連行方程式の導入}

混成モデルの第 2 の特徴は連行を表現する式に渦動粘 性係数 $\varepsilon_{M}$ を導入したことである.すなわち,式(10), (11) はそれぞれ運動量流束ならびに浮力流束の保存式であ り, 従来の積分モデルと同様に, 未知量 $Q, D, W$ の数 が方程式の数を上回っており，解くことはできない. そ こで，次式に示す連行方程式を導入した.

$$
\frac{d Q}{d x}=\frac{\lambda \varepsilon_{M}}{W}
$$

ここに，入は無次元の比例定数である. 上式は次元を合 わせるように採用した関係式であり，いわゆる，Morton et al. ${ }^{5)}$ 流の連行速度の表示とは異なる. その結果, 
式（10）（12）が積分方程式系の基礎式となる.

次に, 式 (10)〜 (12) を式（7)，（8）に代入すれば, 断面積分量はうまく整理されて, 分布関数 $f, \theta$ に関す る常微分方程式が次式のように得られる.

$$
\begin{aligned}
& f^{\prime \prime \prime}+\lambda\left(f \cdot f^{\prime \prime}+f^{\prime 2}\right)+\gamma\left(\theta-f^{\prime 2}\right)=0 \\
& \theta^{\prime \prime}+P_{r} \lambda\left(f \theta^{\prime}+f^{\prime} \theta\right)=0 \ldots \ldots \ldots \ldots \ldots \ldots \ldots \ldots . . .
\end{aligned}
$$

ここに,

$$
\gamma=D W^{3} / \varepsilon_{M} Q
$$

$\gamma=0$ とすれば, 式 (13) は均質噴流の微分方程式とな る. 境界条件を考慮して 2 回積分すれば，その解は Görtler ${ }^{6)}$ が求めた解 $U / U_{\varepsilon}=1-\tanh ^{2} \zeta$ と一致する.

フォーストプルームの場合には $\lambda$ と $\gamma$ をつにまと めるために, Phillips はさらに変数変換を行った.

$$
\begin{aligned}
& F(\xi)=\frac{J}{G(0)} f(\zeta) \\
& G(\xi)=\left(\frac{J}{G(0)}\right)^{4} \frac{1}{\lambda^{2}} \theta(\zeta) \\
& \xi=\frac{\lambda G(0)}{J} \zeta \\
& \text { ここに, } \\
& J=2 \int_{0}^{\infty} F^{\prime} d \xi=2 F(\infty) .
\end{aligned}
$$

式（16）を式（13），(14）に代入すると, 微分方程式系 の基礎式として最終的に次式を得る.

$$
\begin{aligned}
& F^{\prime \prime \prime}+F F^{\prime \prime}+F^{\prime 2}+(\gamma / \lambda)\left(G-F^{\prime 2}\right)=0 \\
& G^{\prime \prime}+P_{r} \cdot(F \cdot G)^{\prime}=0 \cdots \cdots \cdots \ldots \ldots \ldots \ldots \ldots \ldots \ldots \ldots
\end{aligned}
$$

このときの境界条件は式（4）より次のようになる.

$$
\begin{array}{ll}
F(0)=0, & F^{\prime}(\infty)=0, \quad F^{\prime \prime}(0)=0 \\
G(0)=1, & G^{\prime}(0)=0
\end{array}
$$

また，式（12）で導入した比例定数 $\lambda$ は,

$$
\lambda=J^{3} / K
$$

である. $K=2 \int_{0}^{\infty} F^{\prime 2} d \xi$ であることから， $\lambda$ の值は流速 分布形状により規定される.

\section{（3）混成モデルの問題点の検討}

以上の誘導の結果, 断面積分量の $x$ 方向変化を表現 する積分方程式系として式 (10)，(11)，(12）を，また 流速および浮力の $y$ 方向分布形状を表現する微分方程 式系として式（18），(19）と境界条件式（20）を得る. ただし, 常微分方程式の係数は断面積分量の関数となっ ており, 基礎方程式は完全な変数分離になっていない. すなわち, 分布形状は均質噴流の解にみられるような相 似関数ではなく, 流下方向に変化する. したがって, 混 成モデルは両方程式系を連立させて解かなければならな い.

両方程式系を連結するのは連行方程式（12）に導入さ れた渦動粘性係数 $\varepsilon_{M}$ である.一般に, 連行量 $d Q / d x$ は, 次元的考察加代表流速 $Q / W$ に比例するものと仮定し て，次式のように表現される。

$$
\frac{d Q}{d x}=E \cdot \frac{Q}{W}
$$

ここに, $E$ は連行係数と称される.

いま, 連行が乱れ速度 $\sqrt{|\overline{u v}|}$ に比例すると考えると, $d Q / d x$ はPrandtl ${ }^{7)}$ の混合距離 $l$ と渦動粘性係数 $\varepsilon_{M}$ を 用いて次式のように表わされる.

$$
\frac{d Q}{d x} \propto \sqrt{|\overline{u v}|} \propto \frac{\varepsilon_{M}}{l}
$$

混合距離 $l$ として代表幅 $W$ を採用すれば，この関係式 は式 (12) の連行方程式となる. 渦動粘性係数と連行係 数とは現象のとらえ方の違いはあるものの, 乱流輸送と いう同一現象を記述するものであり, 式 (12) の連行過 程の表示は式 (22) と同程度に有効であると考えられる.

微分方程式系基礎式（18）と（19）に含まれる係数の うち $P_{r}$ は $\varepsilon_{M} / \varepsilon_{K}$ で表わされる乱流プラントル数であり， その意味は物理的に明瞭である. 一方, 係数 $\gamma / \lambda$ の物 理的意味は明らかでない. いま, 式 (12) と式 (22)の 関係に式 $(15)$ を考慮すると, $\gamma / \lambda$ は次のように求まる.

$$
\frac{\gamma}{\lambda}=\left(\frac{D W^{3}}{Q^{2}}\right) \frac{1}{E}=\frac{R_{i}}{E}
$$

ここに, $R_{i} \equiv D \cdot W^{3} / Q^{2}$ は断面平均リチャードソン数で ある。

つまり, 係数 $\gamma / \lambda$ は浮力効果とせん断効果の度合い を表わす断面平均りチャードソン数 $R_{i}$ と連行係数 $E$ の 比で表現される変量である. その值は噴流からプルーム への遷移過程で流動とともに変化する.

\section{4. 乱流フォーストプルームへの適用}

\section{（1） 渦動粘性係数の表現}

渦動粘性係数 $\varepsilon_{M}$ に対して Prand $\mathrm{tl}^{7)}$ の第二理論を適用 すれば， $\varepsilon_{M}$ はプルーム軸上の流速 $U_{\varepsilon}$ と代表幅 $W$ との 積で表現されて，次式のようになる.

$$
\varepsilon_{M}=x \cdot U_{\mathfrak{\varepsilon}} \cdot W \cdot
$$

ここに， $x$ は実験的に定められる定数である. Phillips は Reichardt ${ }^{8)}$ の実験に基づいて $x=0.01086$ をフォ一 ストプルームの全流程にわたって与えた。 その結果, 均 質噴流での連行係数が Görtler の解析解の約 2 倍にもな るという不合理な結果を得ている.

一方, 近年の精度高い乱流計測によれば, 噴流からプ ルームへと移行するに伴って，軸上の流速で基準化した 乱流せん断応力ー $\overline{u v} / U_{q}^{2}$ が増大することが明らかに なってきた。たとえば， Ramaprian-Chandrasekhara は軸対称プルームでのレイノルズ応力ー $\overline{u v}$ の測定デー 夕から, $\varepsilon_{M} / U_{\varepsilon} \cdot W_{U}$ (ここに, $W_{U}$ は流速分布の半值半幅 $)$ の值を求め, プルームでの值は均質噴流のそれの約 1.6 倍になることを報告している.つまり, Phillips の論文 ${ }^{1)}$

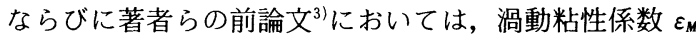


の値は流動の遷移，換言すれば流下距離に無関係に一定 であると仮定していたが，それは合理的でない，理論展 開に際して, $\varepsilon_{M}$ の流下方向変化を考慮する必要がある.

そこで，もう一度基礎方程式（1)，（2）を用いよう. 簡単のために, 流速および浮力の分布関数形を次式のよ うに定義する.

$$
\begin{aligned}
& U / U_{q}=F_{1}(\zeta) \\
& B / B_{q}=G_{1}(\zeta)
\end{aligned}
$$

連続方程式（1）をとに関して0からとまで積分して 得られる横方向流速 $V$ を $x$ 方向運動方程式 (2) に代 入して整理すれば，次式が得られる。

$$
\begin{aligned}
\frac{d}{d \zeta}\left(\frac{\varepsilon_{M} F_{1}^{\prime}}{Q}\right)= & f^{\prime}(0)\left\{\frac{W}{U_{\varepsilon}} \frac{d U_{\varepsilon}}{d x}\left(F_{1}^{2}-\frac{d F_{1}}{d \zeta} \int_{0}^{\zeta} F_{1} d \zeta\right)\right. \\
& \left.-\frac{d W}{d x} \cdot \frac{d F_{1}}{d x} \int_{0}^{\zeta} F_{1} d \zeta-\frac{W}{U_{\varepsilon}^{2}} B\right\} \cdots(26)
\end{aligned}
$$

上式に，積分方程式系 (10)，(11)，(22）加導かれる 次式

$$
\begin{aligned}
& \frac{d Q}{d x}=\frac{1}{2-(\gamma / \lambda)} \cdot \frac{Q}{W} \cdot \frac{d W}{d x} \\
& \frac{d D}{d x}=\frac{-1}{2-(\gamma / \lambda)} \frac{D}{W} \frac{d W}{d x} .
\end{aligned}
$$

ならびに, プルーム軸上の流速值

$$
U_{\varepsilon}=f^{\prime}(0) \frac{Q}{W}
$$

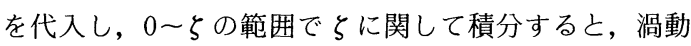
粘性係数 $\varepsilon_{M}$ は次のように求まる.

$$
\begin{aligned}
& \varepsilon_{M}=\frac{f^{\prime}(0)}{F_{1}^{\prime}(\zeta)} \cdot Q \cdot \frac{d W}{d x}\left\{\frac { 1 } { 2 - ( \gamma / \lambda ) } \left(2 \int_{0}^{\zeta} F_{1}^{2} d \zeta\right.\right. \\
& \left.-F_{1} \int_{0}^{\zeta} F_{1} d \zeta\right)-\int_{0}^{\zeta} F_{1}^{2} d \zeta \\
& \left.-\frac{(\gamma / \lambda)}{2-(\gamma / \lambda)} \frac{\theta(0)}{f^{\prime}(0)^{2}} \int_{0}^{5} G_{1} d \zeta\right\}
\end{aligned}
$$

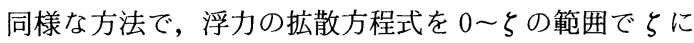
関して積分すると, 渦動拡散係数 $\varepsilon_{\kappa}$ が求まる.

$$
\varepsilon_{K}=-f^{\prime}(0) \frac{1}{2-(\gamma / \lambda)} Q \frac{d W}{d x} \frac{G_{1}(\zeta)}{G_{1}^{\prime}(\zeta)} \int_{0}^{\zeta} F_{1} d \zeta
$$

乱流プラントル数 $P_{r}$ は式 $(30),(31)$ の比として表わ
される.これは最初に仮定した $P_{r}$ と恒等的に一致する. $\varepsilon_{M}$ および $\varepsilon_{K}$ は基礎方程式（2），（3）において流下 距離 $x$ のみの関数と定義しているので, 上式中の積分

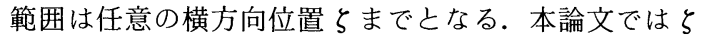
$=\infty$ を採用して積分値を求めた.

\section{（2）混成モデルの展開}

上述した混成モデルの概要を図で示すと，図一1のよ うになる. 乱流プラントル数 $P_{r}$ および係数 $\gamma / \lambda$ を仮定 することにより, 分布関数 $F, G$ に関する非線形微分方 程式系（式（18），(19））を解くことができ, 流速と浮 力の分布形状が求まる. 得られた分布関数形を用いて渦 動粘性係数 $\varepsilon_{M}$ (式 (30)) を算出する. 次に, 渦動粘性 係数 $\varepsilon_{M}$ より連行係数 $E$ が求まり, 式 (23) の $\gamma / \lambda=$ $R_{i} / E$ の関係より, 断面平均リチャードソン数 $R_{i}$ 之連 行係数 $E$ の関係が理論的に求まる. この $E \sim R_{i}$ の関係 を用いて積分方程式系（式 (10)，(11)，(12））を初期 値問題亡して解けば，断面積分量 $Q, D, W$ の流下方向 変化が求まる.

\section{（3）数值解析法}

微分方程式系の分布関数 $F, G$ に関する非線形 3 階常 微分方程式系は 2 点境界値問題となり, 解析的には解け ない. そこで, Bellman の準線形化法 ${ }^{9}$ に基づいて線形 漸化式で近似して解いた. 特解, 斉次解を求める場合に は Runge-Kutta-Gill 法を採用している.

また，断面積分量 $Q, D$ および $W$ に関する積分方程 式系は初期值問題となる. 放出口での $Q_{0}, D_{0}, W_{0}$ を適 宜初期条件として与え， $E \sim R_{i}$ の関係を用いることに より，容易に解ける.

\section{5. 数値解の性質}

\section{（1）平均流速と平均浮力の分布形状}

乱流プラントル数 $P_{r}$ と係数 $\gamma / \lambda\left(=R_{i} / E\right)$ の任意の 値を式 (18)，(19）に代入して解くことにより, 流速と 浮力の分布形状が求まる．P $P_{r}$ および $\gamma / \lambda$ を変化させた ときの分布形状を図一 2,3 に示す。縦軸は軸上の值で

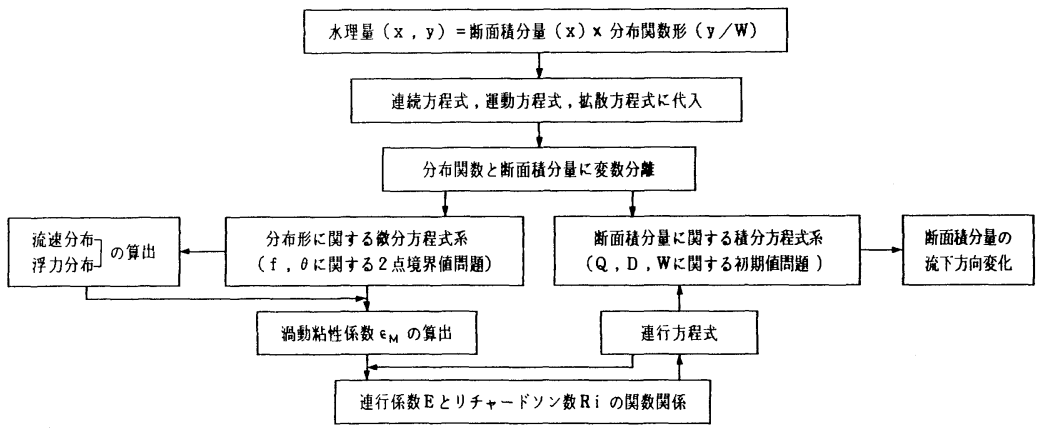

図一1 モデル展開の概要 
無次元表示した流速と浮力を示し, 横軸は流速の半值半 幅 $W_{U}$ で無次元表示した横方向距離 $\eta\left(=y / W_{U}\right)$ を示す.

数值解 $F(\xi)$ および $F^{\prime}(\xi)$ は $P_{r} や \gamma / \lambda$ の值にかかわ らずほとんど変化しない.したがって, 無次元表示した 流速分布 $U / U_{\text {E }}$ はほぼ同一の曲線で近似でき, しかも 均質噴流に対する Görtler の解と同一である。 また, $y / W_{U}<1.5$ の範囲の分布形はガウス分布で近似できる. これに対して, 浮力分布 $B / B_{£}$ は $P_{r}$ および $\gamma / \lambda$ の值に よって鋭敏に変化する. すなわち, $P_{r}$ と $\gamma / \lambda$ の值が小 さくなるにつれて, 軸上浮力が減少し, 横方向の拡がり が増加する傾向がみられる. 軸上浮力 $B_{q}$ で無次元表示 したために $B_{\varepsilon}$ の減少は同図中に表わせないが，たとえ ば，図一2に示す $P_{r}=0.5$ での $B_{\varepsilon}$ の值は $P_{r}=1.0$ の場 合の $67.5 \%$ になる. 乱流プラントル数 $P_{r}$ は渦動粘性 係数と渦動挔散係数との比であり, $P_{r}$ の減少は渦動拡 散係数の増加, すなわち浮力の分布形の拡がりを意味し

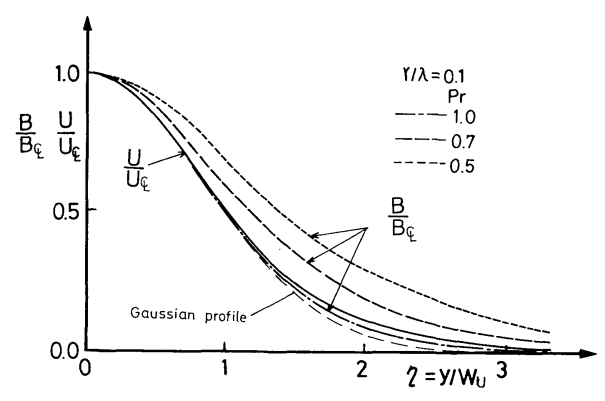

図一2 分布形状に及ぼす $\boldsymbol{P}_{r}$ の影響
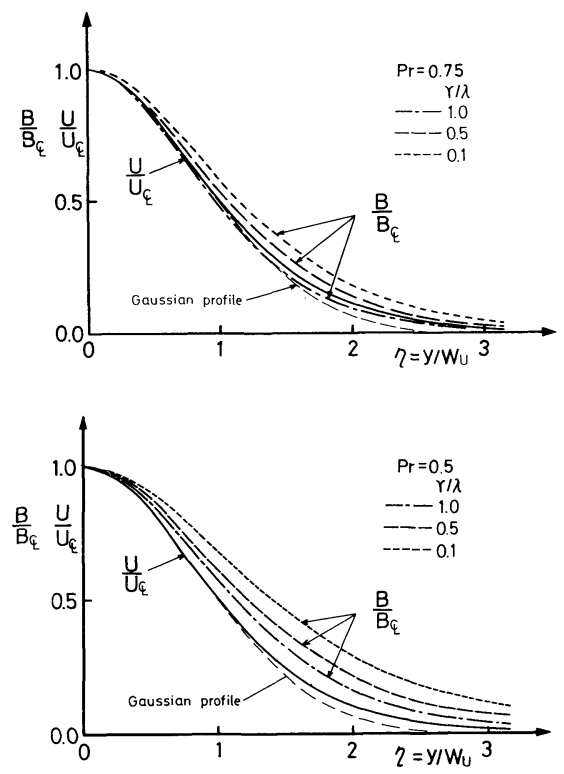

図一3 分布形状に及ぼす $\gamma / \lambda$ 影響
ている.このことは図一2において本混成モデルで矛盾 なく表現されている.

一方, 図一3 は $P_{r}$ を一定にして $\gamma / \lambda$ を変化させた場 合の分布形状を示す. 上図は $P_{r}=0.75$, 下図は $P_{r}=$ 0.5 の計算結果である. 係数 $\gamma / \lambda$ の増加は運動方程式

（18）中の浮力項の増大を意味しており， $\gamma / \lambda$ の増加に 伴って浮力分布は流速分布に漸近する傾向にある. つま り， $P_{r}$ を一定にして分布形を推算しても, 浮力の影響 が増大するにつれて, 実質的な乱流プラントル数が増大 することを意味している.

後述するように，実験により得られたフォーストプ ルームの $P_{r}$ の值は 0.7 〜 0.8 の範囲である. その範囲 では $\gamma / \lambda$ の值の変化が分布形状に及ぼす影響は小さい ことが図一3の上図からわかる.つまり, 噴流からプルー ムへの遷移過程において, 流速ならびに浮力の分布形状 はあまり変化しないことが予想でき, 式（5）の変数分 離は近似的に成立する.

また, 図一2, 3 を浮力分布の半値半幅 $W_{\mathrm{B}}$ を用いて 無次元表示して示せば, 今度は流速分布 $U / U_{\varepsilon}$ が $P_{r}$ あ るいは $\gamma / \lambda$ の值に従って変化するのに対して, 浮力分 布 $B / B_{\S}$ はガウス分布で近似できる一本の曲線で描か れることになる．ただし，その定性的傾向は図一2，3 と何ら変わることはない.

\section{（2）連行係数と断面平均リチャードソン数}

式 (12), (22) より連行係数 $E$ は渦動粘性係数 $\varepsilon_{M}$ と 次式のような関係にある.

$$
\begin{aligned}
E= & \frac{\lambda}{Q} \cdot \varepsilon_{M}=\lambda \cdot \frac{f^{\prime}(0)}{F_{1}^{\prime}(\zeta)} \cdot \frac{d W}{d x}\left\{\frac { 1 } { 2 - ( \gamma / \lambda ) } \cdot \left(2 \int_{0}^{\zeta} F_{1}^{2} d \zeta\right.\right. \\
& \left.-F_{1} \int_{0}^{\zeta} F_{1}^{2} d \zeta\right)-\int_{0}^{\zeta} F^{2} d \zeta \\
& \left.-\frac{(\gamma / \lambda)}{2-(\gamma / \lambda)} \frac{\theta(0)}{f^{\prime}(0)^{2}} \int_{0}^{5} G_{1} d \zeta\right\} \cdots \cdots \cdots \cdots \cdots \cdots \cdots \cdots \cdots \cdots \cdots \cdots
\end{aligned}
$$

つまり, 流速ならびに浮力の分布形状が求まれば, $d W / d x$ をパラメーターとして $E$ を算出できる. また, そのときの $\gamma / \lambda$ の值より, 断面平均リチャードソン数 は $R_{i}=(\gamma / \lambda) \cdot E$ のように求まることになる（式 (23) 参照). 未知量 $d W / d x$ は積分方程式系基礎式 (10), (11) と式 (22) とを連立させることにより，次式のように表 わされる.

$$
\frac{d W}{d x}=2 E-R_{i}
$$

よって, $P_{r}$ と $\gamma / \lambda$ の值を仮定することにより得られる

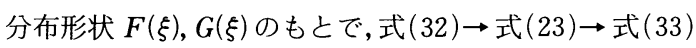
を繰り返し計算することにより,$d W / d x$ の值が理論的 に求まる.

上述の手法により求まる連行係数 $E$ と断面平均り チャードソン数 $R_{i}$ との関係を乱流プラントル数 $P_{r}$ を パラメーターに示したのが図一 4 である. 縦軸は実験值 


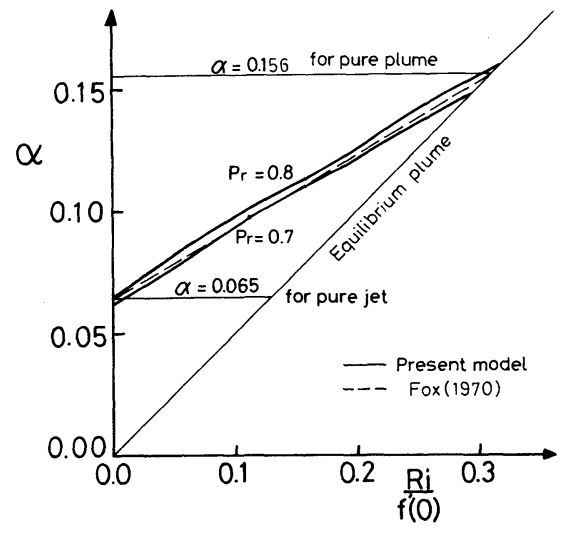

図一4 連行係数とリチャードソン数の関係

および他の解析結果との比較のために, $d Q / d x \equiv 2$ $\alpha \cdot U_{q}$ で定義される慣用的な連行係数 $\alpha\left(=E / 2 f^{\prime}(0)\right)$ を 採用している.

さて, 設定した $\gamma / \lambda\left(\right.$ すなわち,$\left.R_{i} / E\right)$ の值から $E$ と $R_{i}$ の関係を求めるが，その拘束条件を考えてみよう. いま， $R_{i}$ を $x$ で微分して式 (10)，(11)，(22）を用い れば

$$
\frac{d R_{i}}{d x}=\frac{3 R_{i}}{W}\left(E-R_{i}\right) .
$$

となる. 断面平均リチャードソン数が流下方向に変化し ないという条件は $R_{i}=0.0$ と $R_{i}=E$ となり, 前者は均 質噴流に, 後者は平衡プルームに対応している.つまり, 同図中で $R_{i}=0.0$ と $R_{i}=E$ で囲まれる領域が混成モデ ルの適用範囲となる。このことは， $\gamma / \lambda\left(=R_{i} / E\right)$ の值 は均質噴流加らプルームへの遷移に伴い 0.0 加ら 1.0 の 範囲で変化することを意味している。

同図には，乱流プラントル数 $P_{r}$ を 0.7 と 0.8 に仮定 した場合の $E-R_{i}$ の関数関係を実線で示す． $P_{r}$ の流下 方向変化を特定するためには，基礎方程式の数が不足し ている，たとえば，運動エネルギー式を導入することに より $\varepsilon_{M}$ の導出が可能であることから，この $\varepsilon_{M}$ と $x$ 方 向運動方程式から求まる式 (30) とが合致するように繰 り返し計算を行って， $\gamma / \lambda$ に対する乱流プラントル数 $P_{r}$ の值を求めることは理論的に可能である. しかしな がら，図一3の上図にみられるように， $P_{r}=0.75$ では $\gamma / \lambda$ に対する $F$ と $G$ の分布形状の違いはわずかであ り，その差異は数值積分する過程で計算誤差の中に埋没 してしまう。その結果， $\gamma / \lambda$ に対する $P_{r}$ の微妙な変化 を正確に求めることは困難であった。このことから， $P_{r}$ を 0.7 と 0.8 に固定して,$E \sim R_{i}$ の関係を図一4の ように求めた。

理論的に得られた連行係数 $\alpha$ は乱流プラントル数に

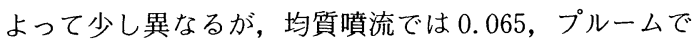

は 0.156 となる。それらの值はそれぞれ Görtler ${ }^{6}$, Rouse et al. ${ }^{10)}$ の実験結果とよく一致している.つまり， 噴流からプルームへと発達するフォーストプルームにお ける乱流プラントル数 $P_{r}$ は 0.7 から 0.8 の範囲にある ことが推察される.この值は中込・平田 ${ }^{11)}$ の実験値 0.71 , 著者 ${ }^{12)}$ の実験値 $0.65 \sim 0.85$, および水科・荻 野ら ${ }^{13)}$ の軸対称プルームの実験值 0.73 と比較して妥当 な値である。

前論文 ${ }^{3)}$ においては，（）均質噴流の連行係数を既往 の実験値に合致するように与えなければならないこと， また， ii ） $P_{r}=0.2$ という実験值からはるかに離れた不 適当な乱流プラントル数を採用しなければ，連行係数と リチャードソン数との関係を矛盾なく説明することがで きないという久点があった．本混成モデルにおいては， 渦動粘性係数 $\varepsilon_{M}$ の流下方向変化を考慮することにより, その矛盾を解消できた。

比較のために図中に破線で示した $\mathrm{Fox}^{2)}$ の表現式 $\alpha=$ $a_{1}+a_{2} \cdot R_{i}$ は質量・運動量の保存式と運動エネルギー式 とを連立させて求めた式であり，本混成モデルの傾向と よく一致している.

以上のように，本混成モデルはフォーストプルームの 連行に及ぼす浮力効果を理論的に誘導できた点で非常に 興味深い。

\section{（3）乱流せん断応力の分布形状}

乱流せん断応力ー $\overline{u v}$ は式（30）の $\varepsilon_{M}$ を用いて表示 できる. 特に, 均質噴流 $(\gamma / \lambda=0.0)$ とプルーム $(\gamma / \lambda$ $=1.0 ）$ に対する乱流せん断応力 $-\overline{u v}$ は無次元表示し て次式のように表わされる.

$$
\begin{aligned}
-\frac{\overline{u v}}{U_{q}^{2}}= & \frac{d W}{d x}\left(\frac{1}{2} F_{1} \int_{0}^{5} F_{1} d \zeta\right) \text { for jet } \cdots \\
-\frac{\overline{u v}}{U_{q}^{2}}= & \frac{d W}{d x}\left\{\int_{0}^{5} F_{1}^{2} d \zeta-F_{1} \int_{0}^{5} F_{1} d \zeta\right. \\
& \left.-\frac{\theta(0)}{f^{\prime}(0)^{2}} \int_{0}^{\zeta} G_{1} d \zeta\right\} \text { for plume }
\end{aligned}
$$

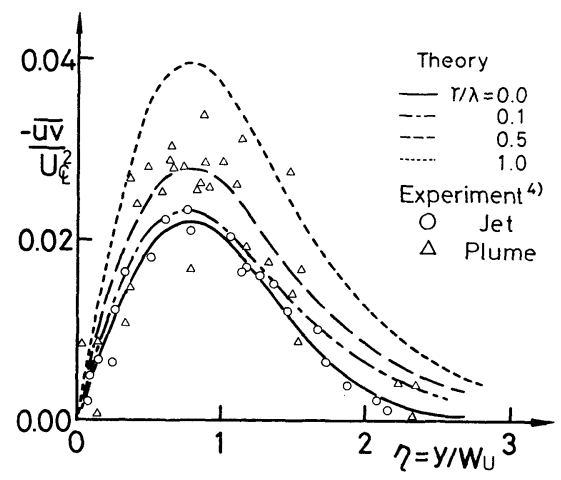

図一5 乱流せん断応力の分布形状 
図一5 は乱流せん断応力の分布形状一 $\overline{u v}(\eta) / U_{q}^{2}$ を $\gamma / \lambda$ をパラメーターとして示す.ただし， $\gamma / \lambda=0.0$ の 噴流解は式 (35) に実験值 $d W_{v} / d x=0.112^{14)}$ を代入し て求めた. 同図より, $\gamma / \lambda$ の値の増大, すなわち浮力効 果の増大に伴い, 無次元乱流せん断応力の絶対值は増加 することがわかる，たとえば，プルームでのー $\overline{u v}(\eta) /$ $U_{\nsubseteq}^{2}$ の最大值は噴流のそれの約 1.7 倍に達している. 図 中のプロットは Ramaprian-Chandrasekhara ${ }^{4)}$ の実験值 を示す．実験值は噴流では理論解とよく一致するが，プ ルームではやや小さめになる. しかしながら，全体の分 布形状に対する理論値と実験値との一致度は満足すべき 結果である.

\section{6. 解析結果の検証}

\section{（1） 水理実験の概要}

検証のための水理実験は前面ガラス張りの水槽（高さ $130 \mathrm{~cm}$, 幅 $90 \mathrm{~cm}$, 奥行 $90 \mathrm{~cm})$ の前面 $15 \mathrm{~cm}$ を仕切っ て行った. 計測水槽の下方から上方へ約 $2 \mathrm{~cm} / \mathrm{s}$ で流れ る一様流中に, 幅 $0.4 \mathrm{~cm}$, 長さ $15 \mathrm{~cm}$ のスリットから 温水を鉛直上向きに放流した．実験装置ならびに実験方 法は著者らの論文 ${ }^{15)} に$ 詳述してある．流速および温度は 計測技研製電磁流速計と高感度サーミスターを用いて計 测した．実験条件は噴流流動とプルーム流動とを網羅す るように, 初期密度フルード数 $F_{d_{0}}\left(=U_{0} / \sqrt{B_{0} W_{0}}\right)$ を 3.5〜64.4 の広範囲に設定した。ここに， $W_{0}$ は放出口

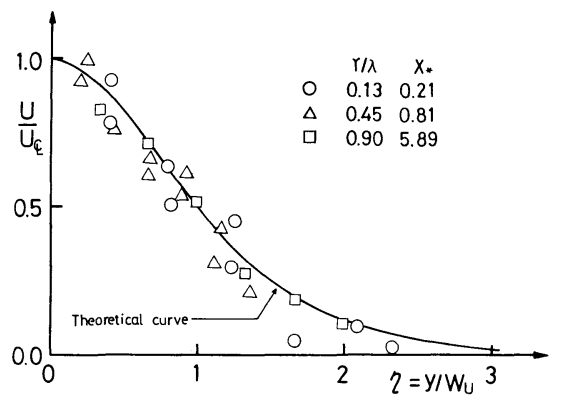

図一6 流速の分布形状

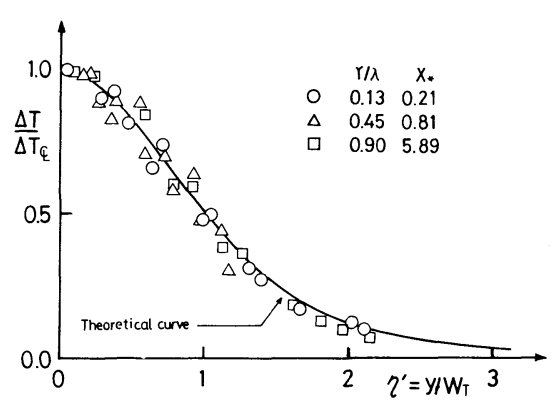

図一7 温度差の分布形状
幅である.なお，解析に用いた乱流プラントル数 $P_{r}$ は, 図一4を参考にして, 全流程にわたって一定值 $P_{r}=0.7$ を採用している.

\section{（２）流速と温度差の断面内分布特性}

図一6,7に流速 $U / U_{\varepsilon}$ と温度差 $\Delta T / \Delta T_{\varepsilon}$ の分布形 状に関する理論値と実験值との比較を示す。ここに, $\Delta T\left(=T-T_{a}\right)$ は周囲流体の温度 $T_{a}$ との温度差を示す. $X_{*}$ は後述する Chen-Rodi ${ }^{14)}$ の無次元距離であり, $X *$ $<0.5$ は噴流領域, $X_{*}>5.0$ はプルーム領域に対応する. また, 横方向距離は流速ならびに温度差の半値半幅で無 次元表示している. 解析条件は測定位置 $X_{*}$ での水理条 件に合わせて決定しており，係数 $\gamma / \lambda$ の值はそれぞれ， $0.13 ， 0.45 ， 0.90$ である. それらの值は後述する $R_{i}^{\prime}, \alpha$ と $X_{*}$ との関係 (図-10亡 11) 加算出した. $y / W_{U}>$ 1.4 の範囲で流速の実験值が理論值に比べて少し小さく なる点を除いて, 流速と温度差の理論値は実験值と良好 に一致している.

\section{（3）水理諸量の流下方向変化特性}

図一8，9 はプルーム軸上の平均流速 $U_{\varepsilon}$ ならびに平均 温度差 $\Delta T_{\notin}$ の逓減特性を示したものである. 縦軸と横 軸は Chen-Rodi の提唱した次式で表わされる無次元量 $U_{*}, T_{*}$ および $X_{*}$ で表わした.

$$
\begin{aligned}
U_{*} & =\frac{U_{\varepsilon}}{U_{0}} F_{d_{0}}^{2 / 3}\left(\frac{\rho_{0}}{\rho_{a}}\right)^{-1 / 3} \\
T_{*} & =\frac{\Delta T_{\notin}}{\Delta T_{0}} F_{d_{0}}^{2 / 3}\left(\frac{\rho_{0}}{\rho_{a}}\right)^{2 / 3} \\
X_{*} & =\frac{x}{W_{0}} F_{d_{0}}^{-4 / 3}\left(\frac{\rho_{0}}{\rho_{a}}\right)^{2 / 3}
\end{aligned}
$$

図中の太線は本混成モデルによる理論解であり, プロッ 卜が実験值である. 初期密度フルード数 $F_{d_{0}}$ は 64.4 , $23.7 ， 6.6 ， 3.5$ であり,Chen-Rodi14) の半経験式を満 たす, いわゆる確立領域では, それぞれ噴流領域, 噴流 から遷移領域, 遷移領域, プルーム領域に相当する. 両 図より理論解は軸上流速 $U *$ と軸上温度差 $T *$ の逓減に 関して実験值と非常によく合致していることがわかる. また, 理論解は Chen-Rodi の逓減則, すなわち, 噴流

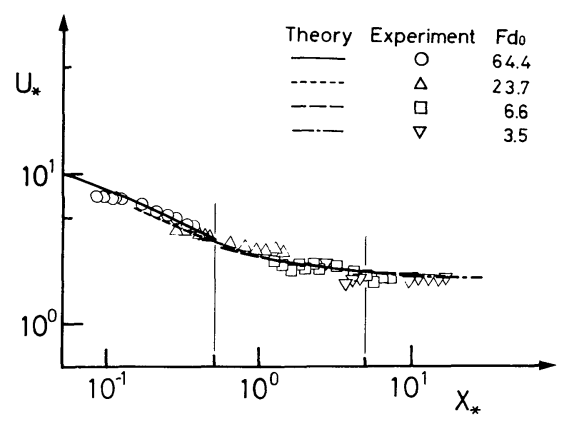

図一8 軸上流速の流下方向変化 


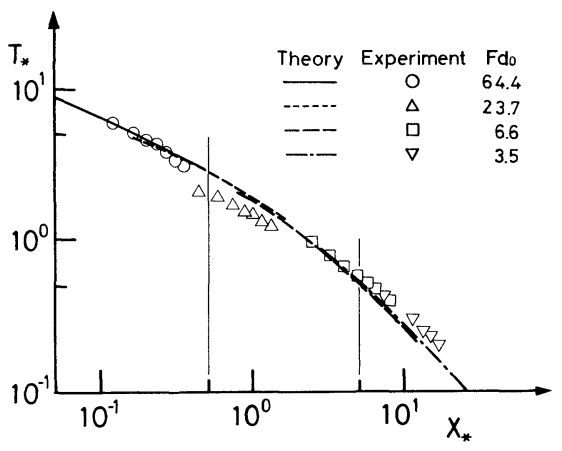

図一 9 軸上温度差の流下方向変化

領域 $\left(X_{*}<0.5\right)$ では $U_{*} \propto X_{*}^{-1 / 2}, T_{*} \propto X_{*}^{-1 / 2}$ ，また プルーム領域 $\left(X_{*}>5.0\right)$ では $U_{*}=$ 一定, $T_{*} \propto X_{*}^{-1}$ の 派減率と合致するばかりでなく, 彼らが多数の実験デー 夕の比較から定めた半経験式ともきわめてよく一致して いる.ただし， $F_{d_{0}}=23.7$ の実験值は少し下方に平行移 動した形でプロットされている．これは後述する断面流 量の流下方向変化特性においても少し特異な傾向を有す ることから，実験の測定誤差に原因するもの之推察され る。

次に，初期条件 $F_{d_{0}}=9.0$ で計算した遷移領域からプ ルーム領域における拡がり率の流下方向変化を表一1に 示す. 流速の半值半幅の拡がり率 $d W_{v} / d x$ は少し増大 する傾向にあるのに対して, 浮力のそれ $\left(d W_{B} / d x\right)$ は 減少する傾向にある. 最終的には流速の拡がり率の方が わずかに大きい。プルーム領域での漸近值は均質噴流の 既往の実験值 $d W_{v} / d x=0.112^{14)}$ より $16 \%$ 程度大きい ことがわかる.また，それらの值 $(0.130,0.128)$ は $d W_{B} / d x$ に関する実験値，たとえば Rouse et al. ${ }^{10)}$ の 0.13 , Kotsovinos ${ }^{16)}$ の 0.12, Anwar ${ }^{17)}$ の 0.131 , LeeEmmons $^{18)}$ の 0.13 と非常によく一致している.

\section{表一1 半値半幅の拡がり率}

\begin{tabular}{c|c|c|c|c|c}
\hline$x / W_{0}$ & 20 & 40 & 60 & 100 & 150 \\
\hline$d W_{D} / d x$ & 0.126 & 0.127 & 0.128 & 0.130 & 0.130 \\
$d W_{B} / d x$ & 0.132 & 0.128 & 0.127 & 0.128 & 0.128 \\
\hline
\end{tabular}

図一10 は，積分方程式系から導出される断面平均り チャードソン数 $R_{i}^{\prime}=\left(D W^{2} / Q^{2}\right) \cdot\left(\theta(0) / f^{\prime}(0)^{2}\right) x$ の流下方 向変化を示す. 流下方向距離は図一8,9に合わせて $X_{*}$ で示した．また，図中のプロットは Kotsovinos ${ }^{14)}$ の実 験値である．理論解は流下方向に滑らかに増大して $X *$ $>30$ のプルーム領域で一定值に漸近する様相を示す.

Kotsovinos の実験值は遷移領域ならびにプルーム領域 で理論値と比較して少し小さめの值となっているが, 全 体の傾向は理論解のそれとよく一致している．両者の差 異については石垣 ${ }^{19}$ が指摘しているように，プルーム領 域において拡がり幅を算出する際に含まれる誤差に起因

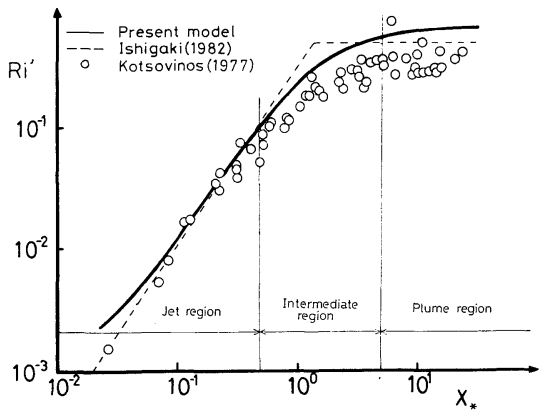

図一10 断面平均リチャードソン数の流下方向変化

しているのかもしれない，また，図中に示した石垣の理 論解は噴流領域とプルーム領域においてのみ適用可能で ある．これに対して，混成モデルの解は両領域での石垣 の值とよく一致すると同時に， $R_{i}^{\prime}$ の変化を流下方向に 連続的に記述できるという点に特徵がある.

図一4 の $\alpha-R_{i} / f^{\prime}(0)$ の理論曲線を用いることによっ て， $R_{i}^{\prime}$ の流下方向変化から連行係数 $\alpha$ を算出できる. $\alpha$ の流下方向変化を示したのが図一11である. 同図よ り， $\alpha$ は $X_{*}<0.1$ では 0.063 の一定值であるが，遷移 領域にさしかかると $\alpha$ の值は急激に増加して, やがて $X_{*}>9.0$ の領域では 0.148 の一定値に漸近してゆくこ とがわかる，つまり，プルームと噴流とでは連行能にお

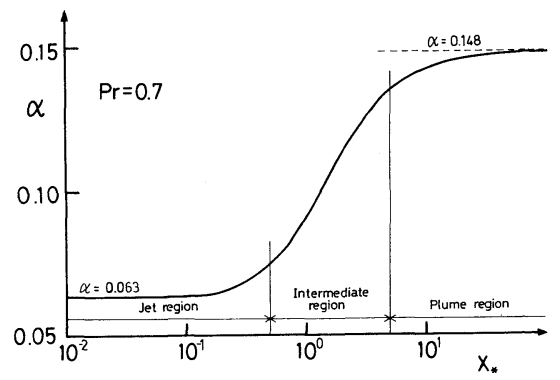

図一11 連行係数の流下方向変化

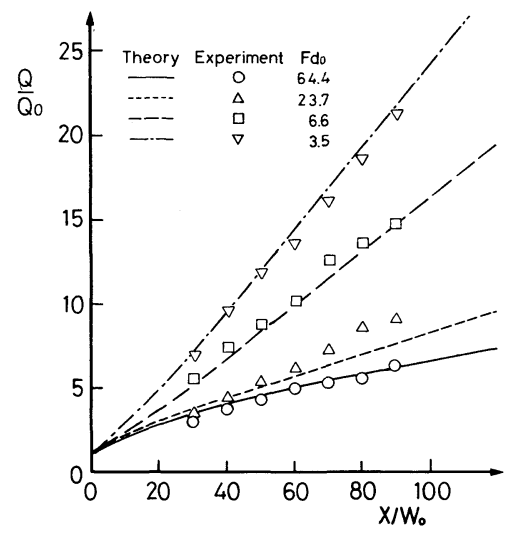

図一12 流量の流下方向变化 
いて約 2.3 倍の差があることを示している.

最後に, 断面積分した流量 $Q$ の流下方向変化の理論 值と実験值との比較を示したのが図一12である. 図中 の曲線は理論解であり，プロットは実験值である．理論 解 $\left(Q(x) / Q_{0}\right)$ は実験值と非常によく一致しており, 初 期密度フルード数 $F_{d_{0}}$ が小さくなるにつれて $Q / Q_{0}$ の増 加率が大きくなるというフォーストプルームの特性を理 論解析はうまく表現している．また， $Q / Q_{0}$ の流下方向 の増加率は $F_{d_{0}}$ の大きい間は非線形に増大してゆくが, 流下に伴って $F_{d_{0}}$ が小さくなると，ほぼ線形に増加して ゆくという理論的結論を，実験結果が裹付けている.

\section{7. 結語}

渦動粘性係数の流下方向変化を考慮した微分・積分混 成モデルを展開することにより，フォーストプルームの 全流程にわたる流動特性を一貫して記述できる理論を構 築した. 本研究で得られた主要な結果は以下のとおりで ある。

（1）混成モデルの特徴は，任意点での水理量を断面 積分量と無次元の分布関数との積で表現することによ り，従来の微分モデルと積分モデルの利点をうまく活用 した理論展開が可能となる点にある.

（２）渦動粘性係数の流下方向変化を厳密に評価した 結果，連行係数之断面平均リチャードンン数の関数関係 が理論的に誘導できた。その結果，連行係数 $\alpha$ は断面 平均リチャードソン数 $R_{i}$ の増大に伴って, 均質噴流の $\alpha=0.065$ からプルームの $\alpha=0.156$ へと非線形に増大す ることがわかった。

（3）その過程で, 乱流プラントル数は 0.7 から 0.8 の範囲で変化する.この值は既往の実験值とよく一致す る.

（4）理論的に導出される平均流速, 平均浮力および 乱流せん断応力の断面内分布は乱流プラントル数 $P_{r}$ と 係数 $\gamma / \lambda\left(=R_{i} / E\right.$ ，換言すれば，浮力効果の度合い) に よって変化する. 理論的に求まる分布形状は実験結果を 良好に予測している.

（5）積分方程式系と連行係数に関する理論式とを連 立させて，断面積分量の流下方向変化を推算した. その 結果, Chen-Rodi の提唱した莪減則ならびに実験結果 とよく合致していることがわかった.

最後に本研究の遂行に熱心に協力して頂いた大阪大学 学生（現・日本道路公団勤務）日置洋平氏に感謝の意を 表します. また, 貴重なご指摘を頂いた査読者に敬意を 表します。

\section{参 考 文 献}

1) Phillips, W.F. : The effect of Froude number on en- trainment in two dimensional line plume, Jour. Fluids Eng., Trans. of the ASME, Vol:103, pp. 471 477, 1981.

2) Fox, G. D. : Forced plume in a stratified fluid, Jour. Geophy. Res., Vol.75, pp. 6818 6835, 1970.

3）室田 明・中辻啓二・日置洋平：2次元フォーストプ ルームの微分・積分混成モデル, 第 30 回海岸工学講演会 論文集, pp. 571 575，1983.

4) Ramaprian, B. R. and Chandrasekhara : Study of Vertical plane turbulent jets and plumes, IIHR Report 257, Univ. of Iowa, p. 402, 1983.

5) Morton, B.R., Taylor, G. I. and Turner, J.S. : Turbulent gravitational convection from maintained and instantaneous sources, Proc. Roy. Soc. London, A 234, pp. 1 23, 1956.

6) Görtler, H. : Berechnung von Aufgaben der freien Turbulenz auf Grund eines neuen Naherungsansatzes, ZAMM, Vol.22, pp. 244 254, 1942.

7) Prandtl, L. : Bemerkungen zür Theorie der freien Turbulentz., ZAMM, Vol.22, pp. 241 243, 1942.

8) Reichardt, H. : Impuls-und Wärmeaustausch in freien Turbulentz., ZAMM, Vol.24, pp. 268 272, 1944.

9）日野幹雄：境界値問題の解法, 朝倉書店, p.210, 1981.

10) Rouse, H., Yih, C. S. and Humphreys, H. W. : Gravitational convection from a boundary source, Tellus, Vol. 4, pp. 201 210, 1952.

11）中込秀樹・平田 賢：二次元サーマルプリュームの乱流 拡散機構, 日本機械学会論文集 (B)，46巻，410 号， pp. 2023 2032， 1980 .

12）室田 明・中过啓二・石田悦一：鉛直上向きプリューム の混合希釈特性について, 土木学会関西支部講演概要, II $-15,1983$.

13）水科篤郎・萩野文丸・武内 洋・和田洋幸 : 鉛直浮力噴 流の乱流機構, 第 19 回日本伝熱シンポジウム講演論文集, pp. 109 111, 1982.

14) Chen, C. J. and Rodi, W. : Vertical turbulent buoyant jets-A review of experimental data, Pergamon Press, p. 83, 1980.

15）室田 明・中过啓二・石田悦一 -日置洋平：二次元 フォーストプリュームの水理特性, 第 31 回海岸工学講演 会論文集, pp. $640 \sim 644,1984$.

16) Kotsovinos, N.E. : Plane turbulent, buoyant jets, Jour. Fluid Mech., Vol. 81, pp. 25 44 and pp. 45 62, 1977.

17) Anwar, H. O. : Experiment on an effluent discharging from a slot into stationary or slow moving fluid of greater density, Jour. Hydr. Res., Vol.7, No.4, pp. 411 430, 1969.

18) Lee, S. L. and Emmons, H.W. : A study of natural convection above a line fire, Jour. Fluid Mech., Vol. 11, pp. 353 368, 1961.

19）石垣 博：乱流噴流の特性に関する研究，第 4 報，日本 機械学会第 918 回講演会講演論文集, No. 820-17, 1982.

(1985.3.22 - 受付) 